\title{
SANATSAL REENKARNASYON
}

\section{Teoman ÇIĞŞAR ${ }^{1}$}

1 Dr. Kastamonu Üniversitesi,Güzel Sanatlar ve Tasarım Fakültesi, Resim Bölümü, tcigsar@kastamonu.edu.tr, ORCID: 0000-0001-6863-5019

Çı̆̆şar, Teoman. "Sanatsal Reenkarnasyon”. idil, 69 (2020 Mayıs): s. 860-873. doi: 10.7816/idil-09-69-10

\section{Öz}

Kültürün en değerli ve verimli kaynaklarından biri de sanattır. Bununla birlikte sanat da kendi çıkış hareketlerini kültürel birikimlerden beslenerek sağlar. Kültürlerin alt yapılarında inançlar, adetler, davranış biçimleri vb. yer alır. Sanatın kendini enkarne ve reenkarne ettiği anlayışları ve ifadeleri, çıkış noktalarıyla ve gerekçeleriyle birlikte ortaya koyma ve bu sayede farklı bir bakış açısı kazandırabilme ümidi; asıl olan amaçtır. Araştırmada da irdelendiği gibi bilhassa din temelli felsefi inançların etkisiyle sanatta yeniden canlandırma çabaları; geleneği, usta-çırak ilişkisini, eserleri korumaya ve devamiyetine yönelik fonksiyonel bir tavırdır.

Anahtar Kelimeler: Kültür, sanat, gelenek, resim, reenkarnasyon 


\section{Giriş}

Reenkarnasyon (Genedoğum), eski dönemlerde olduğu kadar günümüze ulaşmış ve/veya güncel içerisinde yer almakta olan kültürlerde de yaygın bir inanıştır. Çıkış noktası itibariyle her canlı, ölüme; ölümle yaşanacak olan yokoluş gerçeğine, (ölümden sonraki süreç hakkında varsayımlardan öte donelere sahip olmadığından) bilinmez olana/bilinmeyene endişeyle yaklaşır ve refleks orijinli karşı bir duruş sergileyerek var olma direnci oluşturmaya, var olduğunu gösteren hayatiyet değerlerini kuvvetlendirmeye, varlığını güçlü tutmaya ve korumaya gayret eder. Canlı varlıklar içerisinde sadece insan, belli bir süre sonunda biyolojik olarak yok olacağının bilin cindedir; bu bilinçle ve bazen de (içgüdüsel) sezgilerle, yokoluş gerçeğine direnircesine yaşama; yaşadığına dair izler bırakma eğilimi gösterir.

Geçmiş kültürlerin izlerini, şu anki zaman dilimine değin süregelen sosyal yaşam içerikli zanaat ve/veya sanat eserlerinden ya da diğer kültürel öğelerdeki (jeolojik, arkeolojik, etnolojik, ontolojik vb.) yaklaşımlardan görebilmek mümkündür ve bu izler, araştırılması kayda değer bulgu niteliğindedirler. Kültürün en değerli ve verimli kaynaklarından biri olan sanat da kendi çıkış hareketlerini, (alt yapılardaki inançlar, adetler, yaşayış ve davranış biçimleri vb. miras olarak da değerlendirilebilecek) kültürel birikimlerden beslenerek sağlar.

Sanatın kendini enkarne ve reenkarne ettiği anlayışları ve ifadeleri, çıkış noktalarıyla ve gerekçeleriyle birlikte ortaya koyma ve özellikle sanatsal açıdan farklı bir bakış kazandırabilme ümidi son derece önemlidir ve asıl amacı teşkil eden de bir olgudur. Bu doğrultuda literatür taraması ve döküman incelemesi yöntemiyle çalışmadaki irdelemelere yön kazandırılmıştır. Araştırmada da görülmüştür ki bilhassa din temelli felsefi inançların etkisiyle sanatta yeniden canlandırma çabaları; geleneği, usta-çırak ilişkisini, eserleri korumaya ve devamiyetine yönelik fonksiyonel bir tavirdir.

\section{Sanatsal Reenkarnasyon}

Tarih, kültürün taşıyıcısı; kültür de uygarlıkların aynasıdır. Geçmiş ve yaşayan uygarlıkların ortaya koymuş oldukları tüm birikimler, kültürlerine de yansır. Kültürün besleyici ve hayatiyet arz eden ana damarlarından birisi de sanattır. Sanatsal gelişim, kendisini kültürel değerlerin üzerine inşa eder; tarih, uygarlık, inanç, felsefe, sanat ve gelenek kavramları (örfler, adetler, ananeler vb.) iç-içe geçmiştir ve birlikte var olurlar (Çığşar, 2000: 4). Tarihi süreç içerisinde meydana gelen her türlü değerin alışkanlık kazanması geleneği doğurur; geleneğin kendinden sonra gelen dönemlere ve kuşaklara aktarılmasıyla da geleneksel yapılanma oluşur (Karaalioğlu, 1975: 130). Bir başka deyişle, uygarlıkların yansıtıcısı kültür ve kültürlerin sanatsal gelişiminin anlaşılabilmesi; geleneksel yapılanmanın irdelenmesiyle mümkün olabilecektir (Çı̆̆şar, 2000: 4).

"İlkel toplumlarda ve gelişmemiş insan topluluklarında sanat; şarkılar, ağıtlar, danslar, belli dinsel tören ler (büyü törenleri), boyanma gibi yalın bir şekil alabilir. İnsan, (gelişiminde) büyüden büyük destek alırken; büyü zamanla dine, bilime ve sanata dönüşmüştür. Sanat; dil, dans, ritmik ezgi, büyü törenleri gibi bütün biçimleriyle, herkesin katıldığ toplumsal niteliğini hiçbir zaman kaybetmemiştir. Bu bağlamda sanat, büyüyle; büyüye olan inançla başlar" (Fischer, 1979: 46-47 \& Güvenç, 1984: 160-174). "Çeşitli betimlemelerle süslenmiş objeler, özellikle ataların ruhlarına armağan olarak, 'Gök ve Yer Tanrıları' için yapılan dinsel törenlerde ve doğanın diğer büyüsel güçleri için kullanılmıştır” (Bedin, 1985: 3).

"İnanmanın objesi; 'ata-ruhu' yahut herhangi bir doğa olayı, bir doğa objesi, bir totem olabilir. Birçok eski kültür uluslarında olduğu gibi (obje) insanın kendisi, örneğin bir sanatçı tarafından yapılan tanrılığı temsil eden bir tasvir veyahut bir basamaklar düzeni teşkil eden birçok tanrıların tasvirleri olabilir. İnanma, inanma objelerinin çeşitliği, durumu değiştirmez. İnanç, kutsal kabul edilen belli törenlere dayanan 'objelerle' gerçekleşir. Çünkü gerek ilkellerin inandıkları objelerde gerekse eski kültür uluslarının tanrılarının tasvirlerinde, (kendilerince var olduğu kabul edilen) insanüstü, doğaüstü güçler görülmüştür. Bu inanma şekillerinden her birisi, insanla-insanüstü, doğaüstü bir şey arasındaki ilişkiyi sağlamaya çalışır" (Mengüşoğlu, 1988: 202-203). Örneğin: "atlar, imparatorları ölümden sonra cennetin kapılarına kadar götürdüklerine inanıldı̆̆ 1 için sadece tasvir edilmekle kalmamış; imparatorların cesetleriyle birlikte gömülmüşlerdir" (Diyarbekirli, 1972: 27 \& Smith, 1983: 50).

Bilindiği üzere, eski kültürlerin hemen hemen hepsinde çok tanrılı inanma yapısı hakimdir ve diriliş (reenkarnasyon), başka bir alemde; bazen aynı beden ve ruhta bazen de farklı beden ve ruhta yeniden doğuş inancını yansıtır. Defin şekilleri farklı olmakla birlikte, Maya'larda, İnka'larda, Aztek'lerde ya da "Eski Mısır'daki gömülme törenlerinde değişik ikinci yaşam ritüelleri yer alır; ölen kişinin mumyalanmış bedeni ve organları, ölümden sonraki hayatta ihtiyaç duyacağı her türlü eşyası ve hatta sevdiği yiyecekler vb. beraberinde kabre konulur" (Seleck, 1998: 
53). Mısır reenkarnasyon inancına göre; ölen kişi, bu dünyaya ait beden-ruh ve eşyalarıyla başka bir dünyada yeniden doğar. Orta Asya Şamanizmi’nde (Uçmağ / Cennet) ve Kızılderili Şamanizmi'nde de ruhların ölümden sonraki hayatta Cennet'e ulaşacaklarına inanılır. Semavi dinlerde de benzer bir anlayış görülmektedir; Cennet'te yeni bir hayat inancı hakimdir. Musevilik, İsevilik veya İslamiyet'te yer alan ikinci yaşam inancına göre; kişi, yeni bir dünyada yeni bir beden ve ruhla hayat bulur.

"İnanma şekillerine dayalı resimler, inanç anlayışlarını ifade eden olguları ve olayları betimler" (Yuan ve Martin, 1964: 34-35). "Resim yapmak, öteki geleneksel sanatlarda olduğu gibi 'benden içeri olan Ben' ile konuşmak, tanışmaktır. Kişinin ruhunu yüzünde görmesidir. Tanrılı dinlerin önerdiği haliyle; 'Kendini Bil' mektir"' (Güvenç, 1980: 124-127).

Bu yaklaşımı destekler nitelikte bağıntılı ve dikkat çekici bir unsur da Uzakdoğu resim sanatında sıkça kullanılan $\mathrm{Mu}$-fang tekniği sayesinde; eski dönemlere ait herhangi bir sanatsal anlayışın, sanatçının ya da sanat eserinin, ileriki dönemlerde sanatsal geleneğe uygun olarak yeniden gündeme gelmesi (reenkarnasyonu-genedoğumu) mümkün olabilmektedir. "Mu-fang; Çin sanatında bir resmin, özgün yapıta maksimum sadakatle yapılmış kopyasıdır. Amaç, zamanla yıpranan yapıtları yok olmaktan kurtarmak" (Sözen ve Tanyeli, 1992: 165) "ve kopya resim sayesinde Uzakdoğu resim sanatındaki geleneksel değerleri; konu ve kompozisyon bütünlüğündeki teknikleri, usta-çırak ilişkilerini ve eserleri (ustaya ve esere saygıyı) korumak, canlandırmak ve (gündemde) canlı tutmaktır” (Çığşar, 2000: 12). "Çizimlerde öncelikle önem verilen, gerçekliği kaybetmeden "fikrî bir ifadenin canlanmasına ve doğumuna' sebep olmaktır. Resimlerdeki en muhteşem olay ise; (tzu-jan / spontane) doğasına sadık kalarak, fikrin doğuşundaki 'mana'yı (sheng) canlandırabilmektir" (Siren, 1963a: 174). "Bu yaklaşım, önemsiz ve/veya enteresan olmayan birşey gibi görünebilir. Ancak Çinli bir ressama göre; sanatsal açıdan 'olmazsa olmaz' derecede hayatî önemi olan bir husustur" (Siren, 1963b: 62).

"Tang Hanedanlığ 1 (M.S. 618-917) dönemi, Uzakdoğu resim sanatında sıkça kullanılan Mu-fang tekniğine, olgun anlamda 'öncülük' yapmıştı’” (Smith, 1983: 147). “Çin sanatında 'Altın Dönem' olarak kabul edilen bu geniş ve kuvvetli dönem, özellikle etkileri açısından, Çin’de rönesansın yaşandı ğı bir dönemdir ve sanatı himâye eden imparatorların, sanata yapmış oldukları katkılar son derece değerlidir" (Smith, 1983: 140). "Çin sanatında bolca kullanılan at figürlerinin gündeme gelişi de bu döneme aittir" (Mackenzie, 1961: 10). Süvarî sınıfı, Han Hanedanlığı (M.Ö. 206-M.S. 220) döneminden bu yana, imparatorluk orduları için hayatî bir önem arz etmiş; 'safkan' atlara sahip olmak, resimlerini yaptırmak, 'güç ve zenginlik sembolü' haline gelmiştir (Çığşar, 2000: 11). "Ressamlar, imparatorluğun himayesindeki safkan atların resimlerini yapmak üzere, sık sık saraya çağrılmışlardır. Yen Li-Pen (M.S. 600-673), davet üzerine saraya gelerek imparator Tai-tsung'un gözdesi olan savaş atlarının resmini yapmıştır. Orta Asya'nın 1şık-gölge üslûbu, Yen Li-Pen sayesinde Çin'e girmiştir. Çinliler, Yen Li-Pen'i ve üslûbunu; düz sathın özelliğini bozduğundan ve fırça berraklığını bulandırdığından dolayı eleştirmişlerdir” (Sullivan, 1985: 35). "Yine de Yen Li-Pen ve atlar, bu ve sonraki dönemlerde Çinli sanatçılara ilham kaynağı olmuştur" (Mackenzie, 1961: 11).

Eski Çin'de, hiçbir hayvan attan daha büyük bir rol oynamamıştır. Çinliler, özellikle bazı savaş atlarının aslında Cennet'ten gelen at kılığına girmiş ejderhalar olduğuna inandıklarından, savaş atlarını 'Ejderha Atları' olarak adlandırıyorlardı. Tang döneminde at resmi popüler hale gelince, bu 'Gök Hayvanı'nı resmetmek için yeni teknikler geliştirmeye yönelmişler ve doğal olarak at, geleneksel Çin resminin de dahil olduğu çeşitli sanat alanlarında favori bir konu haline gelmiştir. Akhal-Teke (Ahal-Teke) türü, imparatorun kendisi de dahil olmak üzere asillerin ve imparatorluk ailesinin gözdesi konumunda yer almıştır. Atların değeri arttıkça, nadir ırkları betimlemeleri için yetenekli ressamlar sarayda işe alınmıştır. Bunlar arasında, zamanının büyük bir sanatçısı olan Han Gan (M.S. 706 783), atlarını resmetmek üzere imparator Xuanzong (M.S. 695-762) tarafından görevlendirilmiştir.

Sanatçı, çevresindekilere; 'atları daha önceki resimler üzerinde incelemesine rağmen canlı incelenen atların en iyi öğretmenler olduklarından dolayı tercih ettiğini' ifade etmiştir. Batılı meslektaşlarının aksine eski Çin sanatçıları, hayvanların yapısını veya insan vücudunu tanımak için nadiren anatomi çalışmasına başvurmuşlardır ve daha ziyade dış görünüşlerinin dikkatlice izlenmesine güvenmişlerdir. Bu nedenle, geleneksel Çin resminde gösterilen hayvanlar, Batı resmindeki kadar anatomik kesinlikte değildir.

\footnotetext{
${ }^{1}$ Ejderha derisindeki (Sazan balığından esinlenilerek stilize edilen) pulların, resimlerdeki safkan atların üzerinde motif olarak kullanılması; Cennet'ten gelen 'Ejderha Atları' inancına ve (devleti sembole eden Ejderha figürüne istinaden) imparatorluğa ait 'Soylu Savaş Atları' olduklarına vurgu yapılan temsili bir canlandırmadır.
} 


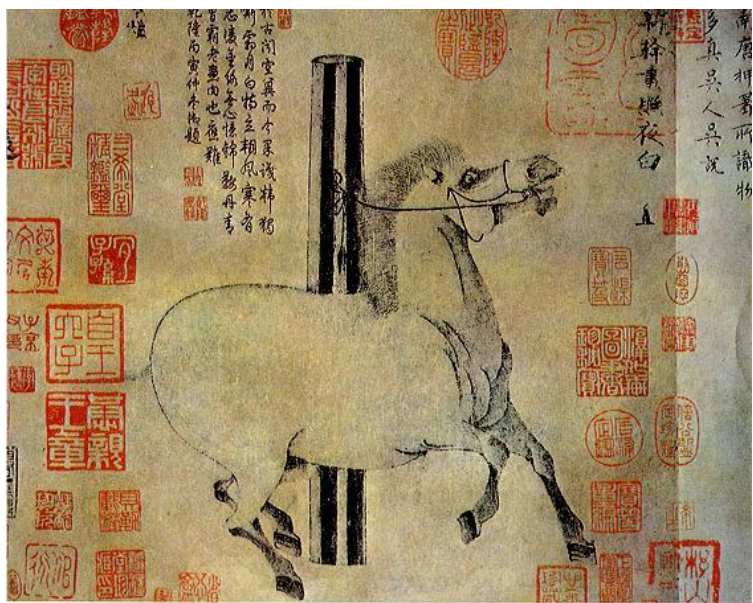

Görsel 1: Han Gan (M.S. 706-783), “Gece Parlayan Beyaz”, Kă̆ıt Üzerine Mürekkep, 30,8 x 34 cm., M.S. 750 (Tang Hanedanlığı / M.S. 618-907), Metropolitan Sanat Müzesi, New York. (Görsel URL-1)

'Gece Parlayan Beyaz', Han Gan'ın gözleyerek resmettiği atlar arasındadır. İmparatorun en sevdiği atının profili, sadece Tang dönemi at resimlerinde bir paradigma değil; Çin resminde de paha biçilemez mücevherlerden biri olarak kabul edilir. (URL-1). "Han Gan, bir atın yalnızca fiziksel benzerliğini değil; ruhunu betimlemesiyle de meşhurdu. Gözündeki korku dolu heyecanı ve başını sinirli bir şekilde geriye atışını, mükemmel bir ifadeyle canlandırmış ve çok büyük övgüler almıştır" (Rowland, 1965: 50 \& Sickman ve Soper, 1971: 181 \& Delacroix, 1980: 461). Dans eden toynaklar1 ve gergin ifadesiyle resmedilen bu at; 'Kan Terleyen' olarak isimlendirilen soylu atlar grubundandır ve nitelikleri itibariyle ejderhalar hakkındaki Çin mitlerine göndermeleri içermektedir. Eser üzerindeki mühürler ve yazılar, Çin sanat uzmanlı̆̆ının ayrı bir özelliğidir. Koleksiyonerler ve sonraki ressamlar tarafından eklenen mühürler ve yorumlar, bir eserin (kopya) iletim bilgilerini kaydeder ve nesiller üzerinde devam eden etkisinin canlı bir ifadesini sunar (URL-2).

"Saray ve dişındaki sanat çevrelerinin, yoğun ilgi ve takdirini toplayan Han Gan, dönemindeki ve sonraki sanatçılara örnek teşkil etmiş; yaptığı resimler kopya edilerek yeniden canlandırılmıştır”" (Siren, 1963a: 26 \& Lee ve Ho, 1968: 189 \& Smith, 1983: 193). Resme konu olan at ve at resimleri, Sung Hanedanlığı'ndaki (M.S. 960 1279) Li Gonglin ve Yuan Hanedanlığı'ndaki (M.S. 1279-1368) Chao Meng-Fu (M.S. 1254-1322) tarafından (Mufang / kopya tekniğiyle) sürdürülmüştür (URL-3).

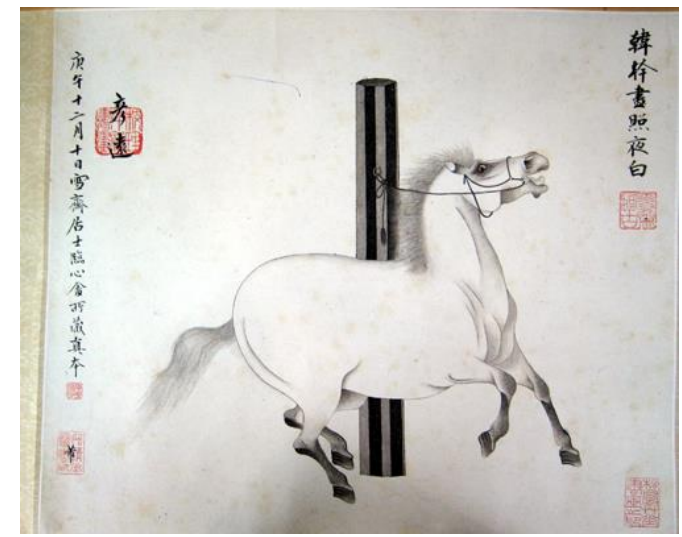

Görsel 2: Yue Fei (M.S. 1103-1142), “Gece Parlayan Beyaz” (Han Gan’dan sonra, 12.-13. Yy.), Kâğıt Üzerine Mürekkep, $30.8 \mathrm{~cm} \times 33 \mathrm{~cm}$., Çin Sanat Müzesi, Çin. (Görsel URL-2) 
Yue Fei (M.S. 1103-1142), Güney Sung Hanedanlığı (M.S. 1127-1279) döneminde yaşayan Çinli bir general, şair, hattat ve ressamdır. Sanatçı, güçlü fırça tekniği ile atın kükreyen başı, bacakları ve vücudundaki mürekkep tonlarının pürüzsüz dokusuna dikkat çekmekle kalmaz; bağlanmış olmanın verdiği rahatsızlıktan kurtulmak isteyen atın, paniğe kapılmış ruh halini yansıtmadaki başarıya da dikkat çeker (tıpkı Han Gan gibi) (URL-4).

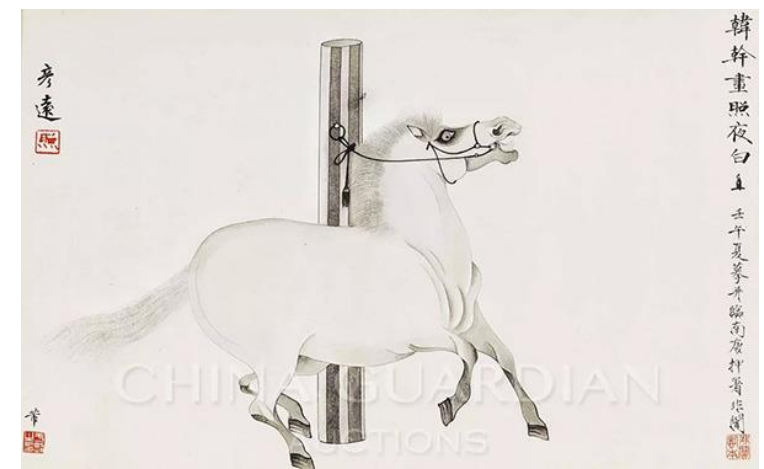

Görsel 3: Yu Feiman (1889-1959), “Gece Parlayan Beyaz” (1942), Kâğıt Üzerine Mürekkep, 28 x 43,5 cm., Ulusal Tarih Müzesi (Taipei), Tayvan, Çin. (Görsel URL-3)

Yu Feiman (1889-1959), Han Gan'ın 'Gece Parlayan Beyaz' eserinden kopyaladığı çalışmasına; açık tonda ve adeta kılları sayılabilir at kuyruğu hatları eklemiştir (URL-5).

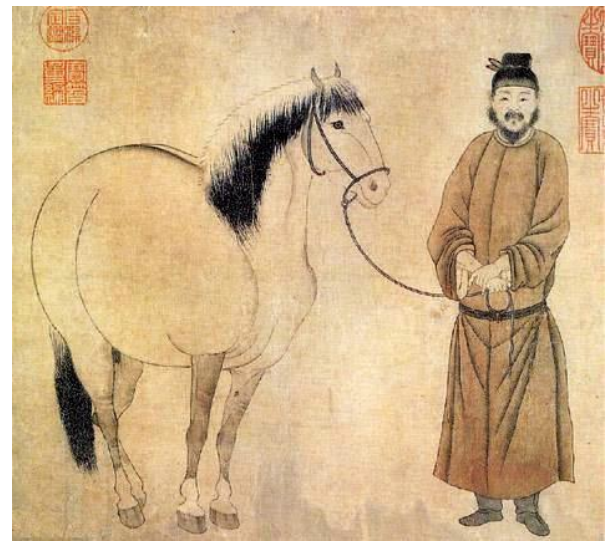

Görsel 4: Han Gan (M.S. 706-783), “At ve Seyis” (M.S. 8. Yy.), Kâğıt Üzerine Mürekkep, 30 x 33 cm., Çin Sanat Müzesi, Çin. (Görsel URL-4)

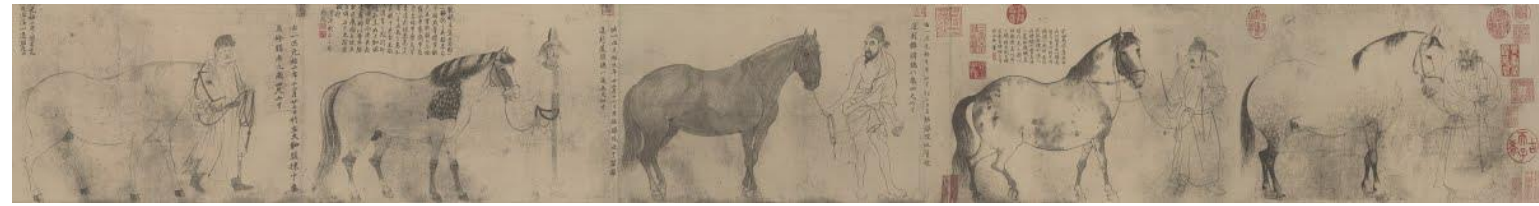

Görsel 5: Li Gonglin (M.S. 1049-1106), "Beş At” (M.S. 1106), Kâğğt Üzerine Mürekkep, 26.9 x 204.5 cm., Özel Koleksiyon, Japonya. (Görsel URL-5) 
'Beş At', Kuzey Sung Hanedanlığı (M.S. 960-1127) ressamı Li Gonglin'in at resimlerinin başyapıtıdır. Ruhla, enerjiyle dolu ve farklı kişilikleri olan atları çizmek için yalnızca tek hamlelik çizgiler kullanmıştır. Atlar koşmamasına rağmen, canlılıkları (hâlâ) hissedebilir. Tang Hanedanlığı'ndaki ressamlarla bile karşılaştırılabilecek kadar sanatında iyi ve başarılı kabul edilmiştir (URL-6). "Bu dönem ressamlarınca antikiteye ve tarihe olan bağlllık geleneği sürdürülmüştür. Resmin yapıldı̆̆ 1 yüzeyde yer alan ögelerin tek köşede toplanması (Tek Köşe Kompozisyonu / Diyagonal Kompozisyon) ortaya çıkmış ve önem kazanmıştır" (De Silva, 1967: 199). "Sung dönemi sanatçıları tarafından Tang dönemine ait resimlerin kopyaları yapılarak, o döneme ait konular ve resimler yeniden canlandırılmıştır” (Sullivan, 1985: 172; Smith, 1983: 177; Hay, 1974: 18).

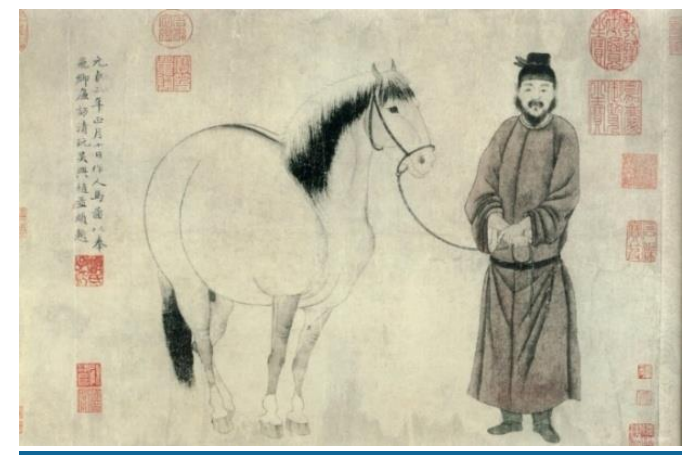

Görsel 6: Chao Meng-Fu (M.S. 1254-1322), “At ve Seyis” (M.S. 1296), Kâğıt Üzerine Mürekkep, 30,2 x 44 cm., Çin Sanat Müzesi, Çin. (Görsel URL-6)

'At ve Seyis' adlı eserde, belirgin bir dizi eğri çizgiden oluşan figürler, düz zemin hattı ve dikey yazıtla çerçevelenen kompozisyonun çarpıcı geometrisi; bir pusula ve/veya kare planla düzenlenmiş gibi görünmektedir. Çince 'pusula-kare' (guiju) terimi, 'düzenleme' veya 'düzen' anlamına gelir. Böylece resim, iyi hükümet için bir metafor ve yanı sıra sanatçının ahlaki doğruluğunun bir ölçüsü olarak da okunabilir (URL-7).

“Çin'de Sung Hanedanlığı'nın sona ermesiyle yerine geçen Yuan Hanedanlığı (M.S. 1279-1368), bir yüzyıldan az bir süre yönetimde kalabilmiştir. Bu sülâleye mensup Moğol hükümdarların hemen hepsi, Çinlilere güvensizliklerine rağmen; hükümet işlerinde çalıştırmak üzere bu bürokratlara ihtiyaç duymuşlardır. Bürokratların çoğu, bilge kişilikli ve yetenekli ressamlardı. Moğolları, at üstünde-savaşta veya birşeyleri kovalarken-avlanırken, atla birlikte resmetmişlerdir. İşte bu dönem, (yeniden) at resimlerinin ve ressamlarının dönemidir" (Sullivan, 1985: 67). "Moğolların, atlara duyduğu önem ve sevgi; resmin seçkin konularından biri olan atları yinelemiştir. Bu rastlantısal bir olgu değil, Moğolların gerçekten at sevgisine dayalı bir durumdur" (Bedin, 1985: 42).

Chao Meng-Fu, Çinli bir edebiyatçı, hattat ve ressamdır. Sung Hanedanlığı soyundan olmasına ve Hanedanlık Akademisi’nde eğitim görmesine rağmen, 1286'da yeni kurulan (işgalci) Moğol Saray İdaresi’nde hizmeti kabul etmiş ve görev yapan edebi ressamlar geleneğinde 'doğanın temsilinden ziyade kişisel ifadeyi arayan genç bir usta' olarak onurlandırılmıştır._Geçmişe atıfta bulunan renk anlayışı ve kompozisyonları, eski ustaların konularından ve tarzlarından türetilmiş bir alakayı göstermek amaçlıdır. Chao Meng-Fu, Tang Hanedanlığı ustası Han Gan tarzında atların ressamı olarak popüler olmuştur (URL-8). "Eski başyapıtların ruhunu ifade edebilme isteğinden dolayı, Tang dönemindeki konular ve Han Gan tarafından yapılmış at resimleri, Chao Meng-Fu tarafından (kopyalanarak) yeniden canlandırılmıştır" (Siren, 1963b: 110 \& Sullivan, 1985: 68).

Her kültür, alış1lagelmiş değerlerinden bunaldığg 1 ve yeniden rağbet görmeyi istediği durumlarda, birdenbire dikkatini; araştırmayı düşünmemiş olduğu (ancak pek çoğu fazlasıyla tanıdık gelen) örneklere yöneltir. Böylece kültür, yenilenme için ihtiyaç duyduğu fikirlere ulaşır veya daha önce ifade etmiş olduğu fikirlerini onaylar. Bu anlayış, 19. yüzyılda Uzakdoğu kültürüne duyulan merak ve ilgiyle tekrar gündeme gelince, Japon baskı sanatını gerçekten anlama ihtiyacına ve yenilenme imkânına yol açmıştır; bu sayede resim sanatı da kendisine 'yeni bir 
çıkış’ bulma arayışına girmiştir (Yamada, 1976: 27). Japon baskıları, İzlenimci sanatçılara ilham vermiş ve farklı sanat biçimine karşı heyecanlarının artmasını sağlamıştır" (Terukazu, 1990: 5).

"Japon sanatı, Çin sanatının kökeni üzerinde gelişmiş ve aynı yolu, yaklaşık bin yıl kadar izlemiştir. Japonya, XIX. yüzyılın yarısında, Avrupa ve Amerika ile ticaret ilişkisi kurmak durumunda kalınca, çoğu ambalaj kâğıdı olarak kullanılan baskı resimlerde, Fransız ressamlarının kurtulmak için can attı̆̆ı ve ne akademik kuralların ne de kalıpların bozabildiği, farklı bir gelenekle karşılaşmışlardır. Japon baskıları, bilinçsiz olarak hâlâ ağırlığını duydukları Avrupa geleneklerinin ayırdına varmalarına yardımcı olmuştur" (Gombrich, 1986: 416). "Japon baskılarının cazibesi; 'tekrara rağmen kendini yenileyerek resmin her alanında başarıya ulaşmış olan' Japon resim sanatının, köklü gelişim sürecinin haklı bir sonucudur. Nitekim, 19. yüzyılın sonunda sadece Japon sanatının etkilediği zarafet ve stil anlayışı nedeniyle, yaygın bir moda gelişim göstermiştir -'Japonizm' ya da 'Japonculuk' adıyla bilinen bir akım- ki; Fransa'da ve günümüze ulaşan etkisi çok güçlü olmuştur” (Terukazu, 1990: 5).

"Japonizm, sanat ve kültür akımı olarak adeta bir yaşam tarzı haline gelmiştir. Klâsik antikite Rönesans için neyse, Japon sanatı da modern sanat açısından aynı derecede önem arz eder. Dönemin yazarları tarafından yazılan yazılarda: 'kompozisyonun parçalanması, form ve renk değerlerinin zenginliği, etkilerin orijinalliği ve aynı zamanda da sadeliğin salt anlatımı sonucunda insanların dayanılmaz bir şekilde etkilendiği' ifade edilmiştir. 1867 Paris Dünya Fuarı'nda, doğrusu bir Japon kültür ve sanat patlaması yaşanmıştır. Batı'nın düşüncesindeki mistik Uzakdoğu, Japonlar tarafından başarılı bir biçimde sunulmuş ve Paris çevreleri, Japon sanatı örneklerinden çok büyük bir haz duymuştur. Japonizm, Batı'da dört temel üzerine inşa edilmiştir: 'Keşfetme, analiz, adaptasyon ve sentez' ...Van Gogh (1853 - 1890), bu dört aşamayı özümseyen nadir sanatçılardan birisidir. İlk üç aşamayı, Paris'te yaşadığı dönemlerde, son aşama olan 'sentez'i de kendindeki Japonizm'i keşfederek bulmuştur” (Walther ve Metzger, 1993a: 283-285).

1885 Ekim'ine kadar, renkçi bir yaklaşım yerine, ışık - gölge oyunlarını ve kalın boya tabakalarını tercih etmiştir. Renge ilgisi, Japon estamplarını keşfetmesiyle artmıştır ve renklerin ne kadar anlatımcı bir araç olduğuna sık sık değinmiştir. Üslûbunu değiştirmeye karar verdiğinde, 1886 Şubat'ında Paris'e varır (Behar, 1984: 6). "Paris'e gittiğinde, Japon baskıları toplamaya başlar (keşfetme). Bu eserleri, 1887'de kendi organizesinde, sanatçıların toplandığı Cafe de Tambourin'de sergiler. Yeni serginin cazibesinden, sosyete dahil herkes çok memnun kalır" (Walther ve Metzger, 1993a: 287).

"Van Gogh zaten evinin duvarlarını 'Ukiyo-e' (Yüzen Dünya Resimleri) eserleriyle dekore etmişti. Tahta baskılar arasında; Hokusai ve Hiroshige gibi ustaların eserleri de yer alıyordu" (Walther ve Metzger, 1993a: 285 286). "Hiroshige, yaptığı çalışmalarla Batı'da en çok tanınan ve bilinen Japon ressamlardan birisiydi." (Phadion, 1996: 218). "Van Gogh, Hiroshige'nin 'Atake Şehir Köprüsü’nde Ani Sağanak' ve 'Kameido'daki Erik Parkı' adlı iki adet baskı eseri ile Kesai Eisen' in 'Oiran (Geyşa)' adlı baskı eserini kopye etmiştir. Bu kopyalar, 'Japon Serisi' olarak adlandırılmıştır ve kopyalama dönemiyle tarzı oturmaya başlamıştır (sentez).

Ustaları önemseyerek yaptığı kopya resimler sayesinde, Uzakdoğu kültürüne ait geleneksel resim sanatının estetik kurgusundan kaynaklanan 'saygı' kavramıyla da tanışmıştır. Zen-Budizm'in felsefi etkisinden kaynaklanan zarafet ve inceliğe dayalı bu saygı anlayışı, sadece Uzakdoğu ile sınırlı kalmamış; kuşaktan - kuşağa aktarılarak, Batı'ya kadar ulaşmıştır" (Walther ve Metzger, 1993a: 290).

"Japon estetizmine göre; sanat, günlük kullanıma ait objelere yer verir ya da günlük kullanım objeleri sanatın kapsamına girer. Sanatın işlevi günlük hatta mümkün mertebe anlık olmalı; sanat ve sanat eseri tazeliğini, canlılığını, dinamizmini kaybetmemelidir. Doğadaki çiçekler, açma zamanı gelince sadece doğada değil; binaların iç duvarlarındaki resimlerde de açarlar. Mevsim kışken, resimler de kışı gösterir; mevsime göre asılır, diğer zamanlarda muhafaza edilmek amacıyla güvenli yerlere (resim kilerlerindeki özel raflara) saygıyla kaldırılır.

Van Gogh da kendi resimlerinde, Japon estetizmine uygun olan bu yaklaşımdan yararlanmıştır (analiz). Hiroshige'den yaptığı kopyalarla keşfetmiş olduğu resimlerinde, kendince yorumladığı kişisel bir izlenimcilik vardır. Japonist etkilerin yer aldığ 1 eserlerindeki 1şık kullanımı, tamamıyla Uzakdoğu resim sanatı anlayışına uygundur. Japon resim sanatında 1şık etkisinin renkle verilmesi, İzlenimciler'e uygun olduğundan Van Gogh tarafından da benimsenmiş ve Japonist eserlerinin hepsinde bu yaklaşıma yer vermiştir" (Yamada, 1976: 18 \& Walther ve Metzger, 1993b: 331). "Japon resim sanatının yüzeysellik ve 1şık etkisi, Van Gogh'un 'Japonist' eserlerinde, kendince sentez edilmiştir. Işık ve gölgenin yerini, güneş 1şığ 1 ve dinamik renkler almıştır; Van Gogh ve çağdaşlarını hayran bırakıp özellikle etkileyen, Japon resimlerinin renkli keskin siluetleridir" (Behar, 1984: 7-8 \& Walther ve Metzger, 1993a: 296).

“(Diyagonal Kompozisyon) 'Yeni Bakış Açısı' ve 'Yeni Renk Armonisi', Van Gogh'u da fazlasıyla 
cezbetmiştir. Komplementer renkleri yan yana kullanarak büyük yüzeyleri, kontrast renkleri yan yana kullanarak küçük yüzeyleri vermeyi denemiş; renklerin (Japon resim sanatında olduğu gibi) farklı kullanımıyla, resimsel dengeye ulaşmayı başarmıştır. Japon resim sanatının 'dekoratif ve yüzeysel etki' anlayışından faydalanarak, kendi yüzeysel metotlarını bulmuştur. Fırça tekniğini değişik bir şekilde uygulamış; Uzakdoğu resim sanatındaki kaligrafik tarzı, Yeni Bakış Açısı ve Yeni Renk Armonisi ile birlikte kendi tarzına 'adapte' etmeyi (üçüncü aşamayı) başarabilmiştir" (Walther ve Metzger, 1993a: 291-292). "Van Gogh bu resimlerde, Uzakdoğu ve Batı'nın sentezini yakalamıştır” (Behar, 1984: 7-8 \& Walther ve Metzger, 1993a: 297).
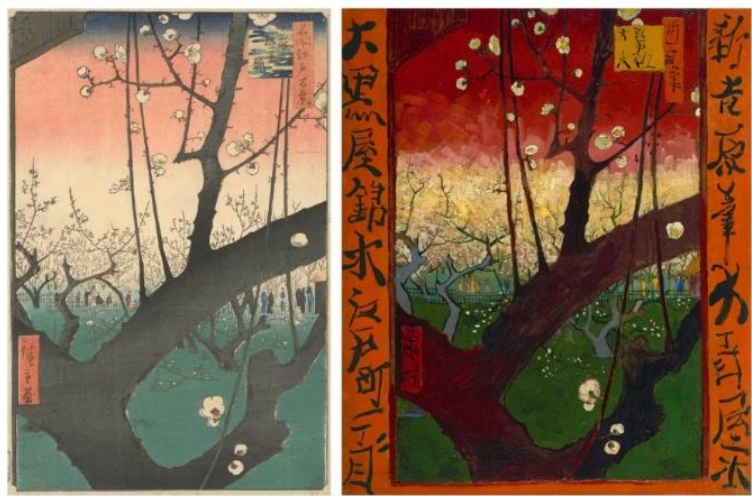

Görsel 7: Soldaki Resim: Ando Hiroshige (1797-1858), "Kameido'daki Erik Park1" (1857), Renkli Tahta Bask1, 25.4 x 37 cm., Van Gogh Müzesi (Vincent Van Gogh Vakfi), Amsterdam, Hollanda. (Görsel URL-7)

Görsel 8: Sağdaki Resim: Vincent van Gogh (1853-1890), "Çiçekli Erik Bahçesi” (Hiroshige'den sonra / Ekim-Kasım 1887), Tuval Üzerine Yağlıboya, 46,8 x 55,6 cm., Van Gogh Müzesi (Vincent van Gogh Vakfi), Amsterdam, Hollanda. (Görsel URL-8)

'Çiçekli Erik Bahçesi' adlı eserin, Van Gogh tarafından (Hiroshige'nin tahta baskılarından) kopya edilen üç yağlıboya tablodan ilki olduğuna inanılmaktadır. Van Gogh, (gölge olmadan) renklerin kullanım tarzı ve konular hakkında çeşitli etkileri araştırmış ve kopyalar yaparak, onları kendine özgü bir tarza dönüştürmüştür.
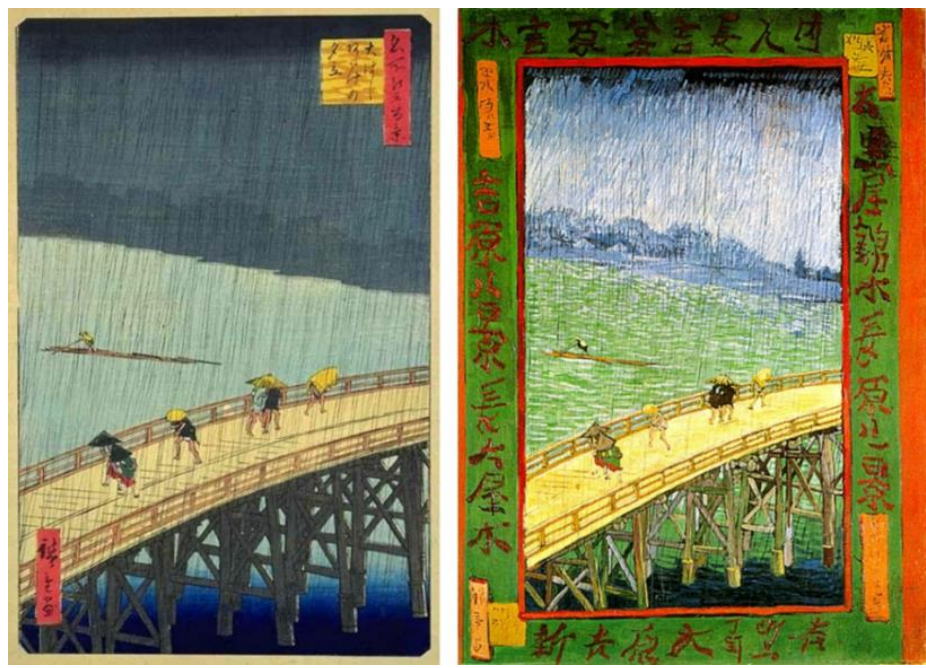

Görsel 9: Soldaki Resim: Ando Hiroshige (1797-1858), “Atake Şehir Köprüsü’nde Ani Sağanak” (1857), Renkli Tahta Bask1, 25,6 x 37,4 cm., Van Gogh Müzesi (Vincent van Gogh Vakfi), Amsterdam, Hollanda. (Görsel URL-9)

Görsel 10: Sağdaki Resim: Vincent van Gogh (1853-1890), “Yağmurdaki Köprü” (Hiroshige'den sonra, 1887), Tuval Üzerine Yağlıboya, 46 x 55 cm., Van Gogh Müzesi (Vincent van Gogh Vakfi), Amsterdam, Hollanda. (Görsel URL-10) 
Hiroshige'nin 'Atake Şehir Köprüsü’nde Ani Sağanak' adlı eserinden, 'Yağmurdaki Köprü’ adıyla yaptığı kopya resimde; orijinal gravür baskının renkli desenlerini takip etmek yerine parlak-kontrast renkleri ve firça darbeleri kullandığı sebebiyle, 'Japon gravürünün cesaretini yumuşattı' şeklinde eleştirel yorumlara maruz kalmıştır. Resmin etrafındaki çerçeveyi dolduran kaligrafik ifadeleri, (anlamlarından ziyade görsel öğe amaçlı kullanmak üzere) başka Japon baskılarından kopyalamıştır (URL-9).

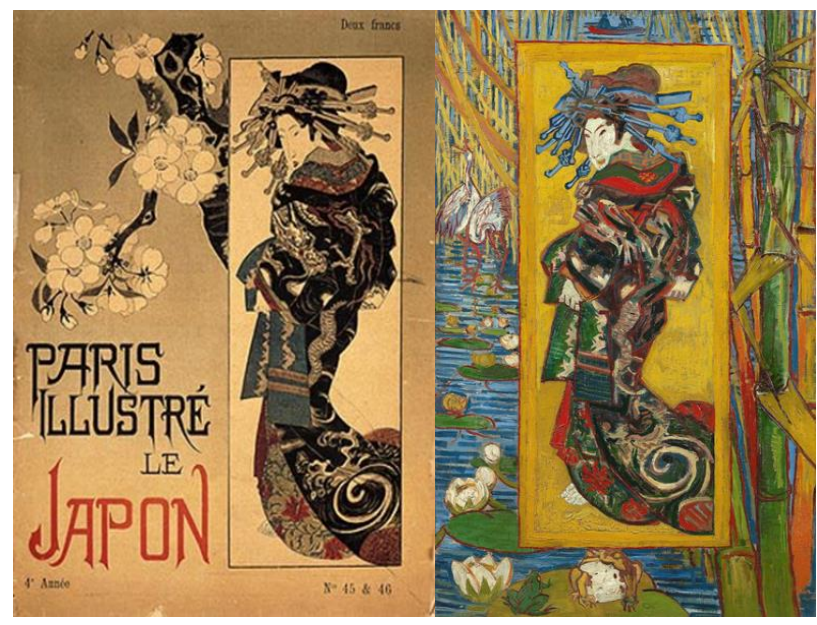

Görsel 11: Soldaki Resim: Kesai Eisen (1790-1848), “Geyşa”, Paris Illustré'nin Kapak Sayfası "Le Japon", Cilt 4, Mayıs 1886, say1 45-46. (Görsel URL-11)

Görsel 12: Sağdaki Resim: Vincent van Gogh (1853-1890), "Fahișe" (Eisen'den sonra, Ekim-Kasım 1887, Paris), Tuval Üzerine Yağlıboya, 100,7 x 60,7 cm., Van Gogh Müzesi (Vincent van Gogh Vakfi), Amsterdam, Hollanda. (Görsel URL12)

Van Gogh bu tabloyu, orijinali Japon sanatçı Kesai Eisen'e ait gravür (tahta baskı) eserin, 1886'da Paris İllustré dergisinin kapağında yer alan resminden etkilenerek yapmıştır. Figürü kopyalamak ve büyütmek için kareleme yöntemini kullanmıştır. Parlak renkler ve koyu tonlu hatlar, adeta bir gravür gibidir. Kadının, saç modeliyle ve giydiği kimonolarının arkadan ziyade önüne bağlanmış (obi) kemeriyle, bir fahişeyi nitelediği söylenebilir. Van Gogh, kadın figürünü; nilüferler, bambu sapları, turna kuşları ve kurbağalarla dolu bir göletle çerçevelemiştir. Kurbağa ve turna kuşu betimlemeleriyle gizli bir göndermede bulunmuştur: Fransızca 'grenouille' (kurbağa) ve 'grue' (turna kuşu) kelimeleri, 19. Yy. Fransız argosunda 'fahişe' ve 'kaldıraç' anlamında da kullanılan kelimelerdir (URL-10). Aynı zamanda "kurbağa, Japon Zen sanatçılarının pek sevdiği bir figürdür. İyi bir meditasyoncu gibi saatlerce kıpırdamadan durur ama bir an bile çevresindeki yaşama karşı uyanıklığını yitirmez" (Güngören, 1995: 161).

"Kültür ve sanat, saygın-oturakl1-önemli (törensel) işlerdir. Yapılan, yaşanılan, sürekli yeniden yaratılan, dinamik ve canlı bir süreçtir" (Güvenç, 1980: 263). Zen-Budizm'i temellendiren "Budizm, sanatı; sanatçıya yalnızca yeni konular esinletmek ile değil, resme büyük bir yenilik sokarak da etkilemiştir: Rönesans'a dek Avrupa'nın tanımadığı bir biçimde, sanatsal buluşlara sanki 'taparcasına bir saygı'yı ekleyerek bunu gerçekleştirmiştir. Doğu dinlerine göre; hiçbir şey, doğru bir biçimde düşünceye dalmaktan veya başka bir deyişle, derinlemesine düşünceye dalmaktan daha önemli olamaz. Düşünceye dalmak ise; akılda bir düşünceyi saptamak ve aynı kutsal gerçeği saatlerce düşünerek tartıp biçmek, hiç dalgınlığa düşmeden onun tüm yönlerini irdelemek demektir. $\mathrm{Bu}$, spora veya beden eğitimine verilen önem gibi Uzakdoğuluların çok önemsedikleri bir tür ussal alı̧şırmadır. Belki de bu, Çin'de dinsel sanatın Buda'ya veya başka Çin bilgelerine ilişkin söylencelerin 
anlatılmasında niçin kullanıldığının; belirli bir öğretinin iletiminden ziyade, düşünceye dalma eylemine bir itki olarak yer verildiğinin nedenidir. Dine inanan sanatçılar, resimlerini saygıyla yaparlar ama bunu derin düşünme gereci sağlamak üzere yaparlar. İşte, en üstün resimlerde saklı olan amaç budur. Sanatlarını, birşey üzerinde yoğunlaşma ve çoğunlukla düşünceye dalma (Meditasyon) yöntemiyle öğrenirler” (Gombrich, 1986: 111-112).

"Japonca olan Zen sözcüğü; Sanskritçe (dhyana) ve Çince (ch'an) sözcüklerinden türetilmiştir. Batı dillerine 'Meditasyon' (sözcüğüyle eş anlamlı) olarak çevrilmiştir. Meditasyon sözcüğü; 'derin derin düşünmek', 'düşünceye dalmak' anlamlarına da geldiğinden eksik veya sınırlı algılandığında yanıltıcı olabilir. Çünkü, Zen'deki uygulama sadece derin derin düşünmeyi değil, zihni; düşüncenin ötesine, düşüncenin ulaşamadığ -ulaşamayacağı- düzeylere yüceltmeyi de amaç edinir" (Suzuki, 1972: 32). "Bilgelik; (Zen-Budizm'e göre) zihni, kavramlardan örülü kafesinden kurtarıp arıtmak ve tam bir iç suskunluğa ulaşmasını sağlamakla mümkün olabilir. Zihni kavramlardan arıtmak denilince, bu kavramların arasına 'boşluk' (kavramı) da konulmalıdır ki zihnin, boşluk kavramına da tutunup sarılmaya çalışmasını engellemek; tam bir iç suskunluğa ulaşmasını sağlamak demektir. Örneğin; daire (çember), ilk aşamada evrenin bütünlüğünü, en son aşamadaysa varlığın arkasındaki boşluğu simgeler" (İdemitsu ve Yardımc1, 1986: 19). Japon Sanatı, modern kavramlarda da yer alan (üçgen, kare, daire) formların evrensel dilini çok önceleri yakalamıştır" (Walther ve Metzger, 1993a: 290).

"Uzakdoğu sanat geleneğinde, insan, doğanın parçası olarak düşünülür ve dolayısıyla doğaya, dışsal ve nesnel yaklaşılmamaktadır. İnsan ve doğa, iç-içe geçmiş (Ying-Yang) haliyle canlı bir bütündür" (Yamada, 1976: 18). "Japonların doğa duyarlılığı, Zen felsefesiyle birleşerek, sanat ve kültür hayatına ruh vermiştir. Yeni bir kendine dönüşün, 'Japon Rönesansı'nın yaratıcı gücü doğmuştur. Çin ve Japon sanatı arasındaki köprüyü, Taoizm inancındaki 'insan - doğa' özdeşliği kurmuştur” (Güvenç, 1980: 133). Zen-Budizm'in bünyesinde yer alan Taoizm'e göre; ilâh fikrinin yerini, doğayla özdeşleştirilmiş bir kuvvet alır ve buna da 'Tao' denilir. Doğada, herşeye can veren ritmik bir hareket (İç Enerji) vardır. 'Ch'i (Öz) - Yün (Ritm) - Sheng (Hayat) - Tung (Hareket)' olarak isimlendirilen bu olgu; 'Hayat Veren Ritmik Öz' olarak tanımlanmaktadır. Hayata dair tüm canlanmalar ve sanata yansıyan canlandırmalar da bu tür inanca dayalı felsefi anlayışlar üzerine inşa edilmiştir” (Siren, 1963a: 174 181 \& Siren, 1963: 61-62).

"Bu sebep-sonuç ilişkisi (Karma), Budizm ve Zen-Budizm'in ana ilkelerinden en önemlisidir" (Arkın, 1969: 800). "İyi ya da kötü eylemler, genedoğumun nedeni olarak kabul edilen sebep-sonuç yasasının; fizik, ruhbilim, toplumbilim alanında olduğu gibi sanatsal alanda da aynı etkinliği sürdürdüğü gözlemine dayalı doktrin" (Güngören, 1995: 218), Budist metinlerde geçen masallarda da yer alır. Buna göre; "Buda gelir ve 'olayın aynısının eskiden de meydana geldiğini, kendisinin daha önceki zamanlarda da yaşadığını' söyler. Böylece, masal aracılığıyla bir taraftan keşişlere Budist öğretiyi aktarırken diğer taraftan da dünyanın oluşumunu, Hint kültürünün temelini oluşturan genedoğum inancını, Budist bakış açısıyla anlatır. Bu inanca göre; ölen her insanın ruhu, yeni bir bedene girmek suretiyle tekrar doğar. Yeni bir bedene giriş, daha önceki duruma ve yapılan eylemlerin sonucuna göre oluşur. Kişinin yaptığının iyi veya kötü oluşunun ödülü veyahut cezası, sonradan daha iyi ya da daha kötü bir bedene giriş biçiminde kendini gösterir" (Ruben, 1995: 218).

"Öyle ise doğmaya, beden bulmaya neden olan şey nedir? Beden bulmaktan, doğmaktan anlatılmak istenen şey; annenin rahmindeki ilk oluştur. Bu ilk oluşun nedeni, var olma arzusudur. Var olma arzusu, beden bulma isteğidir. Yaşamı yaratacak olan unsur, maddi bedeni yakalayıp orada kendisine bir yer bulmak; beden olarak bireysel yaşamak ister. Budistler'e göre; insan öldükten sonra 'Yaşam Unsuru' (Ruh değil), bedeni terk ederek başka bir bedene, yani diğer bir anne rahmindeki cenine girer ve ceninle beraber kalır. Cenin gelişir, doğar, büyür ve ölür. $\mathrm{Bu}$ olay, yaşam unsurunun bir başka anne rahmine girmesiyle sürekli devam eder. Budizm'deki oluş kavramı, evrenin oluşumu değil; daha çok insanların yaşamlarında yaptıkları eylemlerin sonucundaki oluşumdur. İnsanların

\footnotetext{
2 Yaşam Unsuru olarak bahsedilen ancak "ruh değil” diye özellikle vurgulanmış olan ifadeden kasıt; 'Can'dır. Türkçe Can kelimesi, “Çince'de Ch'an / Chan'na (Zen) şeklinde yer alır ve 'Arınma / Arınış / Arınmış / (arınarak) Yeniden Doğuş / Yeniden Doğmuş’ vb. manaları kapsar” (Suzuki, 1972: s.32). Kuran'daki Arapça ifadesiyle 'Karine', Eski Mısır Dili'nde 'Carine / Carne' ve Latince'de de 'Carna' kelime kökünden; Carna-tion, En-carna-tion, Re-en-carna-tion kelimeleri türetilmiş olup, 'Can, Canlı, Canlılık, Canlanma, Canlandırma, Yeniden Canlanma (Genedoğum)' vb. manalardaki kelimelerle dilimizde karşılık bulmuştur. "Can bedenden çıkmayınca, Can çıkmayınca Hu da çıkmaz, Cana gelecek mala gelsin, Cana (veya Canına) Can katmak, Can acısı, Cana kıymak, Can alacak nokta, Can alıcı, Can alıp Can vermek, Canı sıkıldı, Can aldı, Canı gitti, Canı çekti, Can buldu, Canlandı, Canlandırma" (URL-11) vb. Türkçe anonim ifadelerde de yer alan 'Can' kelimesinden kastedilen, dilimizdeki manası ve kullanımı itibariyle salt Ruh ile sınırlı bir yapılanma değil; Ruhaniyet, Ruh’un Kimliği / (bir nevi) Ruh'un Karviziti, "Ruh'un Emaresi (Nefsi Emare), Ruh'a Eşlik Eden" (Daşkıran, 2015: s.151) ve kullanıldığı diğer bazı dillerdeki manası itibariyle de 'Ruh' değil; örneğin "Uzakdoğu Kültürü’nde: Ch’i (Öz) - Yün (Ritm) - Sheng (Hayat) - Tung (Hareket) kelimelerinin sentez isimlendirilmesiyle; Hayat Veren Ritmik Öz / Ruh'un (hayatın, nefesin) Manası, Ruh’un Enerjisi, Ruh’un İç (Ch’i) Enerjisi” (Siren, 1963a: 174-181 \& Siren, 1963b: 61-62) olarak ifade edilmektedir.
} 
geleceğini, yaptıkları eylemler belirler ve her doğuş, bir önceki niteliğine göre oluşur” (Ruben, 1995: 116-117). Beden ölünce; Ruh, 'Alem-i Ervah' olarak ifade edilen 'Ruhlar Alemi'ne gider. Ne zaman ki dünyevi ve ruhani tekâmül, gereğince gerçekleşip sonuçlanırsa; 'Can' da o an kendi alemine (Öz'üne / Tanrı'ya / Yaradan'a / Yaratıcı Güç Kaynă̆ı'na) döner.

\section{SONUÇ}

Sanatçının var olma arzusu, ifade etmek istedikleri doğrultusunda sanat anlayışını doğurur ve sanatsal doğurganlığa (sanat eseri üretimine) sebep olur. Sanatçının yaşam unsuru olan her dönemin sanatında sanatla var olma arzusu, iç dünyasında oluşup olgunlaşırken; yeri ve zamanı geldiğinde bir (veya birçok) eserde doğar, gelişir ve yok olur. Yokoluş sonrasında, sanatsal olarak iki tür genedoğum yaşanır: birincisi sanatçının faal olduğu dönemde, ikincisi sanatçının ölümünden sonraki dönemlerde, sanatsal alanda (ekol, tarz, üslup, eser vb.) yaşanan genedoğumdur.

Sanatsal açıdan eserlerin yeniden canlandırılması, yapım (production) veya yeniden yapım (re-production) kavramlarıyla izah edilip değerlendirilemez çünkü yetersiz ve sınırlı kalmış olur. Mu-fang, (Batı'da olduğu gibi) sadece bir eserin kopyalanmasından ya da kopya yoluyla analitik değerlendirilmesinden ibaret değildir; dönemlerin, geleneğe dair anlayışların ve en önemlisi de eserin ruhunu yeniden canlandırmayı öncelikli hedef kabul eden bir yaklaşımdır. Tam da bu sebeple, geçmiş dönemlerin özellikle de mâlolmuş sanatsal anlayışları ve eserleri, tekrar edilmiş algısına yer bırakmayacak şekilde ve yeni yapıldığı dönem anlayışıyla bağıntılı olarak yinelenir. Örneğin; farklı dönemlerde (7., 11.-12. ve 13.-14. yy.) çok önemsenen at figürlerinin tekrarlanması ancak her yeni anlayışın, eserin ruhuna uygun olarak manasını kaybettirmeden canlandırılmaya özen gösterilmesi gibi.

Çizilen veya resmedilen figür, sadece bir bedendir; asıl olan o bedene ait olduğu düşünülen ruhun, sanatsal mana içerecek şekilde buluşturulabilmesidir. Bu tür bir yaklaşım, elbette kültürel yapısında var olan inanç ve inanca dayalı felsefi anlayışların getirilerinden beslenmektedir ve Asya kültürünün genelinde bu ve buna benzer anlayışlarla sanatsal yaklaşımları görebilmek mümkün ve tabiidir. Budizm ve özelikle de Zen-Budizm anlayışlarındaki 'reenkarnasyon yaklaşımlarının sanatsal bir tezahürü’ olarak değerlendirilebilir.

Örneğin; Çin sanatı, Japon sanatını ve Japon sanatı da Batı sanatını etkilemiştir. Yen Li-pen'in Çin sarayına davet edilmesi ve etkili çalışmalarıyla '1şık-gölge' üslubunu Çin sanatına kazandırması sonucu; o süreçten sonraki çalışmalar kaligrafik ifadelerle sınırlı kalmamış ve 'hacim' kavramıyla da buluşmuştur. Bu, o dönem adına adeta Rönesans ve arınmışlı̆̆ın sanata yansımaları Japon kültüründe ortaya çıkana kadar devam etmiş olan bir süreçtir. Japon kültür ve sanatı, Batı'daki İzlenimciler'e ve özellikle de Van Gogh'un sanat anlayışına etki etmiştir. Sanatçının son dönemindeki sanat yaklaşımı ve eserlerinin, yeni bir anlayışla (Diyagonal Kompozisyon/Yeni Bakış Açısı ve Yeni Renk Armonisi) can bulup doğmasını sağlamıştır.

Her sanatçı, var olma ve daima kalıcı olabilme arzusuyla üretir. Üretilenler de kendi ve kendinden sonraki dönemlerde, yeni üretimleri ve üretilenleri doğurur. Buda'ya göre: 'Yaşam; sürekli bir akış içindedir, sürekli değişimdir. Değişim; sürekli yaşamdır' ...bu hal, bir tür ‘ölümsüzlük' demektir. Sanatçı, sanat yoluyla ölümsüzlüğü seçerek ve ölse de var olma / kalıcı olma arzusunun genedoğum (yaşamdeğişim) ile mümkün ve ölümsüz kılabileceğini farketmekte; böylece resimsel gelenek, usta-çırak ilişkisi ve eserler de (geleneğe, ustaya ve esere sayg1) yeniden üretimlerle yeni ürünlerde reenkarne olabilmektedir. Tüm bu süreçler bütününü, içerik / kapsam / etkileşimler / devinimler ve sonuçları açısından 'Sanatsal Reenkarnasyon' ifadesiyle tanımlamak; yerinde bir yaklaşım olarak değerlendirilebilir.

\section{KAYNAKLAR}

Arkın, Ramazan Gökalp. "Budizm”. Cumhuriyet Ansiklopedisi. C.3. İstanbul: Arkın Kitabevi, (1969).

Bedin, Franca. Çin Sanatını Tanıyalım. Çev. Eren Soley. İstanbul: İnkılap Kitabevi, 1985.

Behar, İsak. Büyük Ressamlar. İstanbul: Kardeş Yayıncılık, 1984.

Çığşar, Teoman. 19.yy. - 20.yy. Çağdaş Batı Sanatı'nda Uzakdoğu (Çin ve Japon) Etkileri. Yayımlanmamış doktora tezi. Ankara: Gazi Üniversitesi, 2000.

Daşkıran, Yaşar. “Temmām Ḥassān'ın Dil Anlayışı: Karineler Teorisi”. Ankara Üniversitesi İlahiyat Fakültesi Dergisi, 56 (Şubat 2015): 149-163.

Delacroix, Horst. Art-Through the Ages. U.S.A.: Harcourt Bracae Jovanovich Co., 1980. 
De Silva, Anil. Art of The World-Art of Chinese Landscape Painting. New York: Crown Puplishers, 1967.

Diyarbekirli, Nejat. Hun Sanatı. İstanbul: Milli Eğitim Basımevi, 1972.

Fischer, Ernst. Sanatın Gerekliliği. Çev. Cevat Çapan. İstanbul: E Yayınları, 1979.

Gombrich, Ernst. Sanatın Öyküsü. Çev. Bedrettin Cömert. İstanbul: Remzi Kitabevi, 1986.

Güngören, İlhan. Zen Budizm-Bir Yaşama Sanatı. İstanbul: Yol Yayınları, 1995.

Güvenç, Bozkurt. Japon Kültürü. Ankara: Türkiye İş Bankası Kültür Yayınları, 1980.

Güvenç, Bozkurt. İnsan ve Kültür. İstanbul: Remzi Kitabevi, 1984.

Hay, John. Masterpieces of Chinese Art. London: Phaidon Press Ltd., 1974.

İdemitsu, Bijutsukan ve Yardımc1, Nurettin. “İdemitsu Koleksiyonu”-Japonya Sanat Sergisi Kataloğu. Japonya: İdemitsu Müzesi, 1986.

Karaalioğlu, Seyit Kemal. Edebiyat Terimleri Kılavuzu. İstanbul: İnkılap ve Aka Basımevi, 1975.

Lee, Sherman ve Ho Wai, Kam. Chinese Art Under The Mongols: The Yuan Dynasty (1279-1368). U.S.A.: Cleveland Museum of Art, 1968.

Mackenzie, Finlay. Chinese Art. London: Spring Books, 1961.

Mengüşoğlu, Takiyettin. İnsan Felsefesi, İstanbul: Remzi Kitapevi, 1988.

Phaidon Ltd. The Book of Art. London: Phaidon Press Ltd., 1996.

Rowland, Jr. Benjamin. Art in East and West. New York: Beacon Press, 1965.

Ruben, Walter. Eski Metinlere Göre Budizm. Haz. Lütfü Bozkurt. İstanbul: Okyanus Yayıncıllk, 1995.

Selleck, Tom. Çöldeki Sır / Piramitler. İstanbul: İnkılap Yayıncılık, 1998.

Sickman, Laurence ve Soper, Alexander. History of Art (The Art and Architecture of China). New York: Penguin Books, 1971.

Siren, Osvald. The Chinese on the Art of Painting-I. New York: Schocken Books, 1963a.

Siren, Osvald. The Chinese on the Art of Painting-II. New York: Schocken Books, 1963b.

Smith, Bradley. China-A History in Art. New York: Harper Books, 1983.

Sözen, Metin ve Tanyeli, Uğur. Sanat Kavramları ve Terimleri Sözlüğü. İstanbul: Remzi Kitapevi, 1992.

Sullivan, Michael. The Book of Art-Chinese Art. V.9. Italy: New Italian Institute, 1985.

Suzuki, Daisetz Teitaro. Introduction to Zen Buddhism. London: Rider and Company, 1972.

Terukazu, Akiyama. Japanese Painting. New York: Rizzoli International Publications, 1990.

Walther, Ingo F. ve Metzger, Rainer. Van Gogh-The Complete Paintings-I. Italy: Benedikt Taschen, 1993a.

Walther, Ingo F. ve Metzger, Rainer. Van Gogh-The Complete Paintings-II, Italy: Benedikt Taschen, $1993 \mathrm{~b}$.

Yamada, Chisaburoh F. Dialogue in Art-Japan and the West. New York: Kodansha International Ltd., 1976.

Yuan, Wang Chi ve Martin, Ruth. Oriental Brushwork. New York: Pitman Publishing, 1964.

\section{İnternet Kaynakları}

URL-1: https://www.shine.cn/feature/art-culture/1807209047/ (e.t.: 02.12.2019)

URL-2: https://www.metmuseum.org/exhibitions/listings/2008/anatomy-of-a-masterpiece/photo-gallery (e.t.: 06.12.2019)

URL-3: https://www.comuseum.com/painting/masters/han-gan/ (e.t.: 08.12.2019)

URL-4: https://en.wikipedia.org/wiki/Yue_Fei\#Biography_of_Yue_Fei (e.t.: 12.12.2019)

URL-5: http://www.cguardian.com/zxzx/jdxw/jpjs/2019/04/12240.shtml (e.t.: 14.12.2019)

URL-6: https://artsandculture.google.com/asset/five-horses-li-gonglin/lwFaBaMSyVepSQ

(e.t.: 18.12 .2019$)$

URL-7: https://www.metmuseum.org/art/collection/search/40507 (e.t.: 20.12.2019)

URL-8: https://www.britannica.com/biography/Zhao-Mengfu (e.t.: 22.12.2019)

URL-9: https://en.wikipedia.org/wiki/Copies_by_Vincent_van_Gogh (e.t.: 26.12.2019)

URL-10: https://www.vangoghmuseum.nl/en/collection/s0116V1962 (e.t.: 06.01.2020) 
URL-11: https://sozluk.gov.tr/?kelime= (e.t.: 08.01.2020)

\section{Görsel Kaynaklar}

Görsel URL-1: https://www.thebostoncalendar.com/system/events/photos/000/165/958/original/Tang WhiteNightHorse.jpg?1518788025 (e.t.: 04.12.2019)

Görsel URL-2: http://blog.voc.com.cn/blog_showone_type_blog_id_460404_p_1.html (e.t.: 10.12.2019)

Görsel URL-3: http://www.cguardian.com/zxzx/jdxw/jpjs/2019/04/12240.shtml (e.t.: 14.12.2019)

Görsel URL-4: https://tr.pinterest.com/pin/386183736775052598/?lp=true (e.t.: 16.12.2019)

Görsel URL-5: https://artsandculture.google.com/asset/five-horses-li-gonglin/lwFaBaMSyVepSQ (e.t.: 18.12.2019)

Görsel URL-6: https://www.metmuseum.org/art/collection/search/40507 (e.t.: 20.12.2019)

Görsel URL-7: https://upload.wikimedia.org/wikipedia/commons/c/cc/Hiroshige_Van_Gogh_1.JPG (e.t.: 24.12.2019)

Görsel URL-8: https://upload.wikimedia.org/wikipedia/commons/c/cc/Hiroshige_Van_Gogh_1.JPG (e.t.: 24.12.2019)

Görsel URL-9: https://i0.wp.com/upload.wikimedia.org/wikipedia/commons/b/b8/Hiroshige_Van_Gogh_2.JPG (e.t.: 30.12.2019)

Görsel URL-10: https://i0.wp.com/upload.wikimedia.org/wikipedia/commons/b/b8/Hiroshige_Van_Gogh_2.JPG (e.t.: 30.12.2019)

Görsel URL-11: https://upload.wikimedia.org/wikipedia/commons/0/03/Title_page_Paris_Illustre_Le Japon vol_4_May_1886.jpg (e.t.: 02.01.2020)

Görsel URL-12: https://en.wikipedia.org/wiki/Japonaiserie_(Van_Gogh)\#/media/File:Van_Gogh_la_courtisane.jpg (e.t.: 04.01 .2020$)$ 


\title{
ARTISTIC REINCARNATION
}

\author{
Teoman Çığşar
}

\begin{abstract}
One of the most valuable and productive resources of culture is art. However, art provides its own movement using culturel accumulation. Within the cultural substructure, there are beliefs, tradition, behaviour patterns $\&$ etc. The perceptions and expressions that art incarnates and reincarnates itself, exhibit together with its point of origin and reasons and by this means expecting a different perspective is the primary objective of it. Accordingly by literature review and document review the action inspections have been accelerated. It has been observed at the research that, the reincarnation efforts, especially under the religious based philosophical belief influence, is a functional attitude, to protect the sustainability of the tradition, master-apprentice relationship and work.
\end{abstract}

Keywords: Culture, art, tradition, painting, reincarnation 